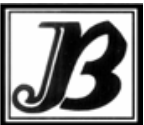

J. bio-sci. 14: 31-38, 2006

ISSN 1023-8654

\title{
EFFICIENT PLANT REGENERATION FROM COTYLEDON AND MIDRIB DERIVED CALLUS IN EGGPLANT (SOLANUM MELONGENA L.)
}

\author{
M Rahman *, ${ }^{1} \mathrm{M}$ Asaduzzaman, ${ }^{1} \mathrm{~N}$ Nahar and ${ }^{1} \mathrm{M}$ A Bari \\ Department of Genetic Engineering and Biotechnology \\ 'Biotechnology Laboratory, Institute of Biological Sciences \\ University of Rajshahi, Rajshahi-6205, Bangladesh.
}

\begin{abstract}
Somatic embryos were obtained from cotyledon and midrib explants of Solanum melongena L., cultivar Loda. For callus induction, medium was supplemented with different concentrations of auxin singly or in combination with BAP. The best callusing $83-85 \%$ was obtained from both of the explants cultured on MS medium containing $2.0 \mathrm{mgl}^{-1} \mathrm{NAA}+0.05 \mathrm{mgl}^{-1} \mathrm{BAP}$. Somatic embryogenesis and shoot regeneration was achieved after transferring the calli to MS medium supplemented with BAP, GA 3 , NAA and Zeatin. Cotyledon derived calli showed better performance $(87 \%)$ for regeneration than that of midrib $(82 \%)$ when sub cultured on MS medium having $2.0 \mathrm{mgl}^{-1}$ Zeatin $+1.0 \mathrm{mgl}^{-1}$ BAP. For root induction, MS +3.0 $\mathrm{mgl}^{-1}$ IBA was proved to be better treatment for average number $(14-15)$ and mean length $(12 \mathrm{~cm})$ of roots than those of other treatments.
\end{abstract}

Key words: Eggplant, cotyledon, midrib, callus induction, somatic embryo.

\section{Introduction}

Eggplant is a common vegetable crop of Bangladesh. It has high nutritive value and can well be compared with tomato (Choudhury 1976). Eggplant is one of the most common, popular and principal vegetable crops in Bangladesh as well as it grow in the most parts of the world. It is also one of the world most important crops by virtue of volume produced and its contribution to our national economy (Uddin et al. 2004). It is grown for home consumption in almost all families near their homestead and more particularly in rural areas, even if may only a few plants in every house (Zahurul 1969). A number of cultivars are grown throughout the country depending upon the yield, consumer's preference about the colour, size and shape of various cultivars (Bose et al. 1999).

Now a day's tissue culture techniques are widely being used for the improvement of various crops. In vitro shoot induction from callus culture can induce genetic and epigenic changes in the regenerated plants. These genetic changes have been coined "somaclonal variation" (Larkin et al. 1986). The diverse characteristics of somaclones highlight the fact that somaclonal variation may be an additional tool for crop improvement rather than an interesting scientific phenomenon (Evans and Sharp 1986, Bajaj 1990). Callus induction and its subsequent plant regeneration is a major way to generate somaclonal variation. Moreover, plant regeneration through callus culture is one of the most important steps for any kind of genetic transformation research (Alam et al. 2002). In plant tissue culture the developmental pathway of numerous well-organized, small embryoids resembling the zygotic embryos from the embryogenic potential somatic plant cell of the callus tissue or cells of suspension culture is known as somatic embryogenesis (Kumar 1995).

\footnotetext{
${ }^{*}$ Corresponding author.
} 
Therefore, reproducible protocol should be established on callus induction and its subsequent plant regeneration for using the techniques of somaclonal variation of the studied genotype in eggplant. In the present study, efforts have been made to establish a protocol for efficient plant regeneration from callus culture in eggplant, cultivar Loda using cotyledon and midrib (Danielle et al. 1988) as explants.

\section{Materials and Methods}

Loda cultivar of eggplant (Solanum melongena L.), commonly cultivated in the northern region of Bangladesh, was selected for the study. Seeds were aseptically grown in culture vessels. For initial establishment of callus culture, 3 weeks old in vitro grown seedlings were used as the source of explants. Cotyledon and midrib isolated from the in vitro grown seedlings were cultured for callus induction and subsequent somatic embryogenesis.

\section{Callus induction and somatic embryogenesis}

Cotyledon and midrib explants were taken from the in vitro grown plants of 3 weeks old. Both explants were excised with the aid of scalpel blade and collected in a petridish. Then the explants were laid on the sterile tile using sterile forceps and were cut into segments of 2-3 $\mathrm{mm}$ with the help of a scalpel blade. The explants were then placed on the medium having MS nutrients (Murashige and Skoog 1962) supplemented with various concentrations and combinations of 2,4-D, NAA, IAA and BAP with $3 \%$ sucrose and solidified with $0.7 \%$ agar. The $\mathrm{PH}^{\mathrm{H}}$ was adjusted to 5.8 before autoclaving at $121^{\circ} \mathrm{C}$ for $20 \mathrm{~min}$. The explants were cultured in petridishes $(9 \mathrm{~cm})$ and maintained in the culture room at $25 \pm 2^{\circ} \mathrm{C}$ under a $16 \mathrm{~h}$ photoperiod (cool-white fluorescent tube supplying). Each petridish contained 18-20 pieces of explants for both cotyledon and midrib.

After 4 weeks, the induced calli were sub-cultured on fresh medium with new hormonal supplements for further proliferation and somatic embryogenesis.

\section{Regeneration}

Plants were regenerated by transferring the suitable embryogenic calli in MS semisolid medium supplemented with 2,4-D, NAA, GA3, BAP and Zeatin at various concentrations and combinations. Within 3-4 weeks of inoculation, masses of 15-20 shoots were developed from each callus, which were sub divided and cultured separately for further proliferation and root induction. The cultures were inoculated at $25 \pm 2^{\circ} \mathrm{C}$ under $16 / 8 \mathrm{~h}$ light/dark condition. Proliferated shoots should have proper root development for successful establishments of plantlets in natural condition. Shoots of 2-3 cm were placed in MS medium supplemented with different concentrations and combinations of IBA and $\mathrm{GA}_{3} . \mathrm{MS}_{0}$ and $1 / 2$ strength of $\mathrm{MS}$ were also treated for root induction.

\section{Results and Discussion}

\section{Callus induction}

Callus was initiated within a period of 10-20 day of culture and a mass of callus was formed within 3-4 weeks. The nature of callus was friable and white creamy to light green in colour and the results of their performance are presented in Table 1. 
Table 1. Effect of auxin (2, 4-D, NAA and IAA) singly or in combination with BAP employed in MS media on callus induction.

\begin{tabular}{|c|c|c|c|c|c|c|c|c|c|}
\hline \multirow{2}{*}{\multicolumn{2}{|c|}{$\begin{array}{c}\text { Growth regulators used in the } \\
\text { treatment }\end{array}$}} & \multicolumn{8}{|c|}{ Types of explants inoculated } \\
\hline & & \multicolumn{4}{|c|}{ Cotyledon } & \multicolumn{4}{|c|}{ Midrib' } \\
\hline Combination & $\begin{array}{c}\text { Concentration } \\
\qquad\left(\mathrm{Mg}^{-1}\right)\end{array}$ & $\begin{array}{l}\text { Days to } \\
\text { Callus } \\
\text { initiation }\end{array}$ & $\begin{array}{c}\% \text { of explants } \\
\text { responded } \\
(\bar{X} \pm S E)\end{array}$ & $\begin{array}{c}\text { Weight / } \\
\text { Callus (gm) }\end{array}$ & $\begin{array}{l}\text { Nature of } \\
\text { Callus }\end{array}$ & $\begin{array}{l}\text { Days to } \\
\text { Callus } \\
\text { initiation }\end{array}$ & $\begin{array}{c}\% \text { of explants } \\
\text { responded } \\
(\bar{X} \pm S E)\end{array}$ & $\begin{array}{c}\text { Weight / } \\
\text { Callus } \\
\text { (gm) }\end{array}$ & $\begin{array}{l}\text { Nature of } \\
\text { Callus }\end{array}$ \\
\hline \multirow{7}{*}{$2,4-D$} & 0.01 & 18 & $26.73 \pm 0.71$ & 0.30 & SW & 18 & $27.40 \pm 0.67$ & 0.28 & SW \\
\hline & 0.05 & 14 & $28.75 \pm 0.96$ & 0.50 & SW & 15 & $29.25 \pm 1.00$ & 0.52 & SW \\
\hline & 0.10 & 13 & $30.38 \pm 1.25$ & 0.70 & SW & 13 & $29.75 \pm 0.74$ & 0.68 & SW \\
\hline & 0.50 & 13 & $48.00 \pm 1.12$ & 0.73 & SW & 12 & $47.25 \pm 1.47$ & 0.78 & SW \\
\hline & 1.00 & 12 & $59.25 \pm 0.82$ & 1.10 & SW & 12 & $58.25 \pm 2.247$ & 1.00 & SW \\
\hline & 2.00 & 8 & $97.10 \pm 0.47$ & 1.35 & SW & 9 & $96.55 \pm 1.14$ & 1.30 & SW \\
\hline & 3.000 & 8 & $86.03 \pm 0.83$ & 1.21 & SW & 10 & $87.89 \pm 3.07$ & 1.01 & SW \\
\hline \multirow{7}{*}{ NAA } & 0.01 & 18 & $29.335 \pm 2.39$ & 0.30 & FG & 17 & $32.86 \pm 1.31$ & 0.31 & FG \\
\hline & 0.05 & 15 & $31.825 \pm 3.08$ & 0.51 & FG & 16 & $34.75 \pm 1.76$ & 0.52 & FG \\
\hline & 0.10 & 13 & $42.75 \pm 1.71$ & 0.75 & FG & 12 & $45.05 \pm 2.27$ & 0.74 & FG \\
\hline & 0.50 & 11 & $43.85 \pm 1.48$ & 0.60 & FG & 13 & $46.36 \pm 2.33$ & 0.75 & FG \\
\hline & 1.00 & 9 & $61.90 \pm 3.17$ & 1.09 & FG & 9 & $62.41 \pm 1.63$ & 1.11 & FG \\
\hline & 2.00 & 8 & $98.60 \pm 0.62$ & 1.40 & FG & 8 & $98.50 \pm 0.29$ & 1.39 & FG \\
\hline & 3.000 & 8 & $95.25 \pm 1.32$ & 1.22 & $\mathrm{FG}$ & 8 & $95.25 \pm 2.43$ & 1.20 & $\mathrm{FG}$ \\
\hline \multirow{7}{*}{ IAA } & 0.01 & 20 & $29.13 \pm 1.74$ & 0.23 & HW & 20 & $31.19 \pm 1.20$ & 0.24 & $\mathrm{HW}$ \\
\hline & 0.05 & 18 & $35.73 \pm 1.13$ & 0.30 & HW & 18 & $34.48 \pm 1.44$ & 0.30 & HW \\
\hline & 0.10 & 17 & $43.95 \pm 0.89$ & 0.28 & $\mathrm{HW}$ & 17 & $45.68 \pm 1.67$ & 0.30 & $\mathrm{HW}$ \\
\hline & 0.50 & 17 & $56.88 \pm 1.64$ & 0.50 & $\mathrm{HW}$ & 18 & $56.30 \pm 2.28$ & 0.49 & $\mathrm{HW}$ \\
\hline & 1.00 & 15 & $65.20 \pm 1.67$ & 0.55 & $\mathrm{HW}$ & 15 & $65.75 \pm 1.63$ & 0.65 & $\mathrm{HW}$ \\
\hline & 2.00 & 14 & $78.00 \pm 0.65$ & 0.60 & HW & 14 & $80.38 \pm 2.84$ & 0.68 & HW \\
\hline & 3.00 & 13 & $86.88 \pm 0.49$ & 0.75 & $\mathrm{HW}$ & 13 & $85.20 \pm 2.06$ & 0.70 & $\mathrm{HW}$ \\
\hline \multirow{7}{*}{ 2,4-D+BAP } & $1.0+0.05$ & 12 & $60.00 \pm 2.68$ & 0.85 & SW & 13 & $60.80 \pm 1.49$ & 0.80 & SW \\
\hline & $2.0+0.05$ & 13 & $74.75 \pm 0.95$ & 1.20 & $S G$ & 10 & $71.50 \pm 1.85$ & 1.02 & $S G$ \\
\hline & $3.0+0.05$ & 10 & $65.25 \pm 1.65$ & 1.05 & SW & 11 & $62.25 \pm 1.11$ & 0.83 & SW \\
\hline & $1.0+0.01$ & 13 & $54.00 \pm 2.58$ & 0.84 & SW & 15 & $61.13 \pm 1.05$ & 0.79 & SW \\
\hline & $2.0+0.01$ & 12 & $72.50 \pm 1.71$ & 1.10 & $H G$ & 12 & $73.75 \pm 2.06$ & 0.99 & $H G$ \\
\hline & $3.0+0.01$ & 13 & $61.75 \pm 0.63$ & 0.95 & HW & 12 & $64.50 \pm 1.71$ & 0.85 & HW \\
\hline & $2.0+1.00$ & 15 & $69.25 \pm 1.65$ & 1.10 & $\mathrm{HW}$ & 15 & $71.25 \pm 1.65$ & 0.89 & $\mathrm{HW}$ \\
\hline \multirow{7}{*}{$N A A+B A P$} & $1.0+0.05$ & 13 & $51.50 \pm 2.36$ & 0.78 & SW & 13 & $52.25 \pm 1.65$ & 0.85 & SW \\
\hline & $2.0+0.05$ & 8 & $82.50 \pm 0.96$ & 1.30 & FG & 9 & $84.50 \pm 2.26$ & 1.16 & $\mathrm{FG}$ \\
\hline & $3.0+0.05$ & 9 & $73.75 \pm 0.85$ & 0.90 & FG & 9 & $74.75 \pm 1.49$ & 1.06 & FG \\
\hline & $1.0+0.01$ & 13 & $50.50 \pm 1.56$ & 0.78 & $\mathrm{HW}$ & 13 & $51.25 \pm 2.50$ & 0.74 & $\mathrm{HW}$ \\
\hline & $2.0+0.01$ & 12 & $67.25 \pm 2.50$ & 1.10 & $H G$ & 12 & $65.50 \pm 2.60$ & 1.08 & $H G$ \\
\hline & $3.0+0.01$ & 12 & $62.75 \pm 1.84$ & 0.92 & $H G$ & 13 & $64.25 \pm 1.65$ & 0.92 & $H G$ \\
\hline & $2.0+1.00$ & 11 & $66.00 \pm 2.12$ & 1.09 & $\mathrm{HG}$ & 11 & $63.75 \pm 2.72$ & 0.91 & $\mathrm{HG}$ \\
\hline \multirow{3}{*}{ IAA+BAP } & $1.00+0.05$ & 15 & $56.75 \pm 1.25$ & 0.30 & $\mathrm{HW}$ & 17 & $60.25 \pm 3.52$ & 0.31 & $\mathrm{HW}$ \\
\hline & $2.00+0.05$ & 16 & $48.75 \pm 1.11$ & 0.34 & $\mathrm{HW}$ & 17 & $50.50 \pm 1.26$ & 0.33 & HW \\
\hline & $3.00+0.05$ & 14 & $55.75 \pm 1.18$ & 0.31 & $\mathrm{HW}$ & 16 & $58.25 \pm 2.14$ & 0.32 & HW \\
\hline
\end{tabular}

Note: Each treatment consisted of 20 explants and data were recorded after 28 days of culture.

Among various concentrations and combinations of 2,4-D, NAA, IAA and BAP, callus induction efficiency was highest when NAA and 2,4-D were used individually, but the highest regenerable calli were obtained when BAP was added to the media composition (Fig. 1). 


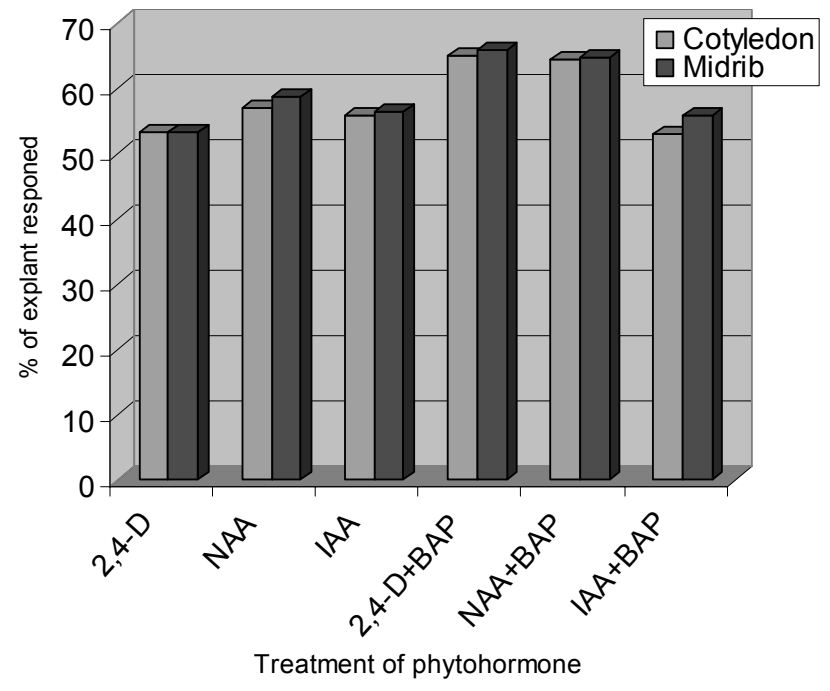

Fig. 1. Graph showing the comparative effect of phytohormone on functional callus induction.

In regards of regenerable calli, best results were recorded when NAA $\left(2.0 \mathrm{mgl}^{-1}\right)$ and BAP $\left(0.05 \mathrm{mgl}^{-1}\right)$ were used combinely for both types of explants (Fig.2 A). The callus induction frequency ranged from 83 to 85 and the required days was $8-9$, when treated with NAA $2.00 \mathrm{mgl}^{-1}+$ BAP $0.05 \mathrm{mgl}^{-1}$. In this case, the callus is friable green $(F G)$ and regenerable in nature. Satisfactory results were also observed in NAA $2.00 \mathrm{mgl}^{-1}, 2,4-$ D $2.00 \mathrm{mgl}^{-1}, 2,4-\mathrm{D} 2.00 \mathrm{mgl}^{-1}+$ BAP $0.05 \mathrm{mgl}^{-1}$ ranging from $71 \%$ to $99 \%$. In this case, the callus is either spongy white (SW) or hard white (HW) and non-regenerable in nature. The use of those hormones for callus induction was also reported by others (Singh et al. 1984, Haider 1992, Hena 1991). The concentration (w/v) of carbon sources was also important for callus induction. When mannitol or sorbitol was added with sucrose, the induced callus became harder instead of being loose or watery. Less than two percent of sucrose resulted low percent of callus induction. This could be due to different osmotic potential between the explants and medium used (Ishak et al. 1992). In this cultivar, the frequency of callus induction was higher in cotyledon than midrib explants. This difference in callus induction may be due to different types of explants and its cellular totepotency (Zelcer et al. 1984, Niedz et al. 1985).

\section{Somatic embryogenesis and regeneration}

The morphology of calli changed when subcultured on MS medium supplemented with Zeatin $2.00 \mathrm{mgl}^{-1}+$ BAP $1.00 \mathrm{mgl}^{-1}$, NAA $2.00 \mathrm{mgl}^{-1}+$ BAP $0.05 \mathrm{mgl}^{-1}$ and GA $30.05 \mathrm{mgl}^{-1}+$ BAP $1.00 \mathrm{mgl}^{-1}$ (Table 2). Almost all the calli were proliferated and turned to develop nodular structures and subsequently embryo like structures in different shapes (globular, heart and torpedo) appeared (Fig 2 B). Days to embryo initiation, number of embryo/callus and percentage of shoot regeneration were studied and the results are presented in Table 2. However, regeneration from globular somatic embryo of eggplant was first reported by Hena (1991) from calli of cotyledon and hypocotyl explants. 
Table 2. Effect of sub-culture on somatic embryogenesis and regeneration efficiency from the unorganized calli derived from cotyledon and midrib in eggplant. Each treatment consisted of 20 explants (best calli obtained from the cotyledon and midrib) and data were recorded after 52 days $(28+24)$ of culture.

\begin{tabular}{|c|c|c|c|c|c|c|c|}
\hline \multicolumn{2}{|c|}{$\begin{array}{l}\text { Combination of growth } \\
\text { regulators used in } \mathrm{mgl}^{-1}\end{array}$} & \multicolumn{6}{|c|}{ Types of explants from which the callus derived } \\
\hline \multirow[b]{2}{*}{$\begin{array}{l}\text { Pre-culture } \\
\text { (28 days) }\end{array}$} & \multirow{2}{*}{$\begin{array}{c}\text { Sub- } \\
\text { culture } \\
\text { ( } 24 \\
\text { days) }\end{array}$} & \multicolumn{3}{|c|}{ Cotyledon } & \multicolumn{3}{|c|}{ Midrib } \\
\hline & & $\begin{array}{l}\text { Days to } \\
\text { embryos } \\
\text { initiation }\end{array}$ & $\begin{array}{c}\text { No. of } \\
\text { embryos } \\
\text { / callus }\end{array}$ & $\begin{array}{l}\% \text { of shoots } \\
\text { regenerated } \\
\text { from the calli }\end{array}$ & $\begin{array}{l}\text { Days to } \\
\text { embryos } \\
\text { initiation }\end{array}$ & $\begin{array}{c}\text { No. of } \\
\text { embryos } \\
\text { / callus }\end{array}$ & $\begin{array}{l}\% \text { of shoots } \\
\text { regenerated } \\
\text { from the calli }\end{array}$ \\
\hline 2,4-D+BAP & & & & & & & \\
\hline $1.00+0.05$ & 足 & -- & -- & -- & -- & -- & -- \\
\hline $2.00+0.05$ & 舟 & -- & -- & -- & -- & -- & -- \\
\hline $5.00+0.05$ & 웅 & -- & -- & -- & -- & -- & -- \\
\hline $1.00+0.10$ & $\stackrel{+}{9}$ & -- & -- & -- & -- & -- & -- \\
\hline $2.00+0.10$ & $\stackrel{+}{\sim}$ & -- & -- & -- & -- & -- & - \\
\hline $5.00+0.10$ & 잉 & -- & -- & -- & -- & -- & -- \\
\hline $2.00+1.00$ & & -- & -- & -- & -- & -- & -- \\
\hline $1.00+0.05$ & & -- & -- & -- & -- & -- & -- \\
\hline $2.00+0.05$ & 足 & -- & -- & -- & -- & -- & -- \\
\hline $5.00+0.05$ & 욷 & -- & -- & -- & -- & -- & -- \\
\hline $1.00+0.10$ & $\underset{+}{+}$ & -- & -- & -- & -- & -- & -- \\
\hline $2.00+0.10$ & ৫ & -- & -- & -- & -- & -- & - \\
\hline $5.00+0.10$ & 웅 & -- & -- & -- & -- & -- & -- \\
\hline $2.00+1.00$ & & -- & -- & -- & -- & -- & -- \\
\hline$N A A+B A P$ & & & & & & & \\
\hline $1.00+0.05$ & 是 & -- & -- & -- & -- & -- & -- \\
\hline $2.00+0.05$ & ñ & $9-12$ & 15 & 76 & $10-12$ & 15 & 71 \\
\hline $5.00+0.05$ & Oे & -- & -- & & -- & -- & -- \\
\hline $1.00+0.10$ & $\stackrel{+}{5}$ & -- & -- & & -- & -- & -- \\
\hline $2.00+0.10$ & ¿ & -- & -- & & -- & -- & -- \\
\hline $5.00+0.10$ & 이 & -- & -- & & -- & -- & -- \\
\hline $2.00+1.00$ & & -- & -- & & -- & -- & - \\
\hline $1.00+0.05$ & & $10-13$ & 14 & 32 & $10-13$ & 13 & 32 \\
\hline $2.00+0.05$ & 岩 & $9-12$ & 17 & 65 & $10-12$ & 17 & 62 \\
\hline $5.00+0.05$ & 일 & -- & -- & & -- & -- & -- \\
\hline $1.00+0.10$ & $\underset{+}{+}$ & -- & -- & & -- & -- & -- \\
\hline $2.00+0.10$ & 志 & -- & -- & & -- & -- & -- \\
\hline $5.00+0.10$ & 5 & - & -- & & -- & -- & - \\
\hline $2.00+1.00$ & $0^{\circ}$ & -- & -- & & -- & -- & - \\
\hline$N A A+B A P$ & & & & & & & \\
\hline $1.00+0.05$ & 을 & $10-13$ & 15 & 72 & $9-13$ & 16 & 78 \\
\hline $2.00+0.05$ & 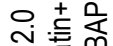 & $10-13$ & 18 & 87 & $10-13$ & 17 & 80 \\
\hline $5.00+0.05$ & 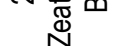 & $12-15$ & 10 & 56 & $11-14$ & 11 & 57 \\
\hline $2.00+1.00$ & & $11-13$ & 17 & 79 & $10-12$ & 15 & 82 \\
\hline
\end{tabular}

In the present study it was proved that use of BAP, $\mathrm{GA}_{3}$ and Zeatin in MS medium induced somatic embryogenesis from eggplant callus derived from cotyledon and midrib. Various concentrations and combinations of NAA, BAP, $\mathrm{GA}_{3}$ and Zeatin were tested in the shoot-inducing medium to determine the optimum combination and concentration for shoot induction. The summarized results are presented in Table 2.The best results for plant 
regeneration from both type of explants were obtained in medium containing a combination of Zeatin 2.00 $\mathrm{mgl}^{-1}+\mathrm{BAP} 1.00 \mathrm{mgl}^{-1}$ (Fig $2 \mathrm{~B}$ ). In this treatment the range of shoot regeneration frequency varied from 80$87 \%$. In other treatments it was either low or moderate (31-79\%). Like callus induction, shoot regeneration was also found better when $3 \%(\mathrm{w} / \mathrm{v})$ of sucrose was used. Less than $3 \%(\mathrm{w} / \mathrm{v})$ of sucrose used in MS medium resulted low number of shoot regeneration. This result is also supported by Anisuzzaman et al. 1992. Between the two explants, the cotyledon was found more responsive than the midrib for somatic embryogenesis and subsequent plant regeneration. This difference may be due to cellular totipotency of the two explants.
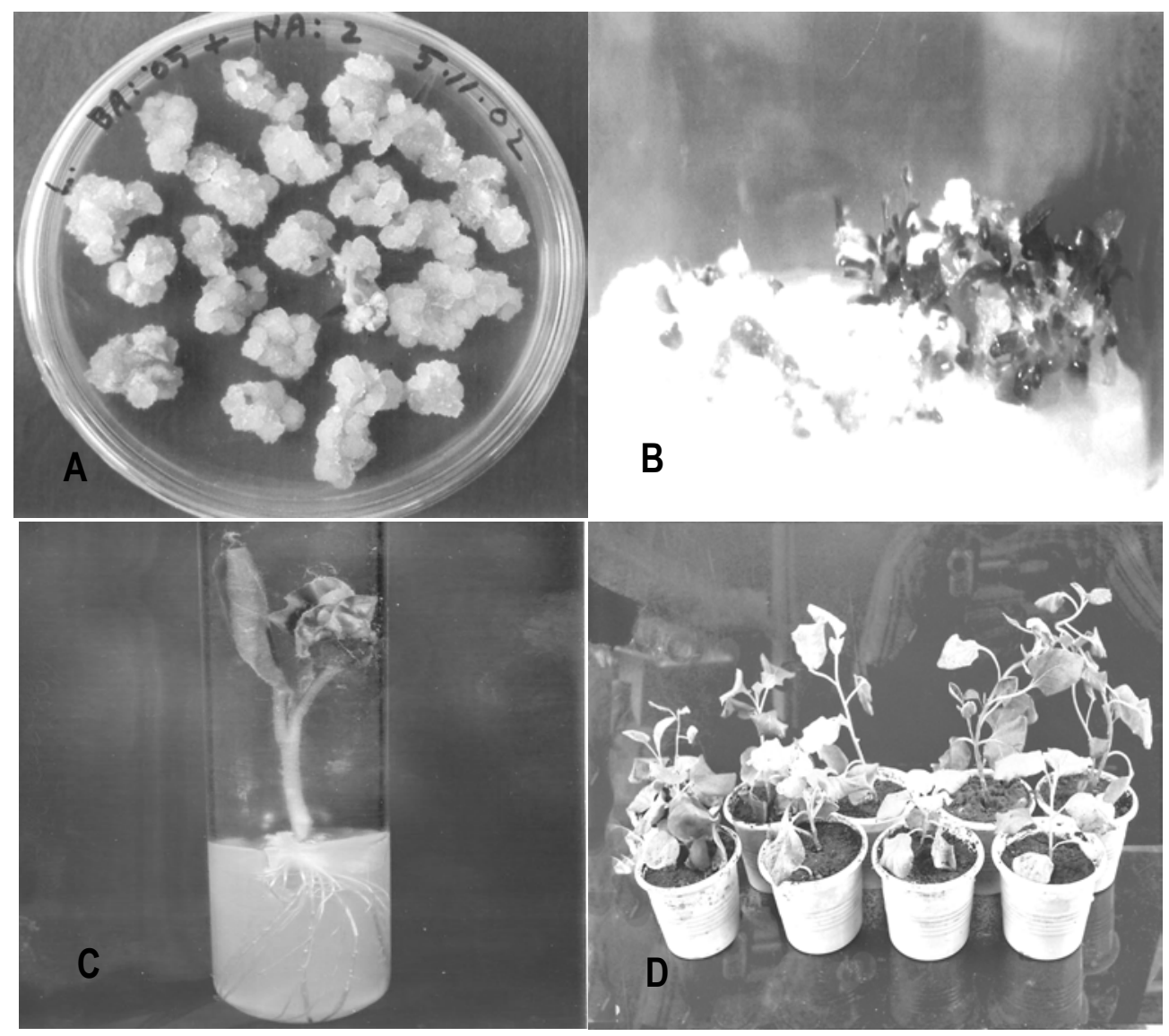

Fig. 2. Plant regeneration through callus culture in eggplant.

A: Friable greenish embryogenic callus on $\mathrm{MS}+2.0 \mathrm{mgl}^{-1} \mathrm{NAA}+0.05 \mathrm{mgl}^{-1} \mathrm{BAP}$.

B: Embryo development and regeneration on MS+2.0 Zeatin+1.0 BAP.

C. Root induction from elongated shoot on $\mathrm{MS}+3.0 \mathrm{mgl}^{-1} \mathrm{IBA}$

D: Establishment of somatic embryo derived plantlets in polar pot under natural condition (7 days after planting in polar pot). 


\section{Root induction}

The elongated shoots $(<4 \mathrm{~cm}$ long) were transferred to rooting medium for root induction. Different combinations of medium were tested for better root development. Root initiation was observed within 6-13 days of subculture. The days to root initiation, average number of roots/shoot and the mean length of roots were observed from 5-28 days of culture and the recorded data are presented in Table 3.

Table 3. Effect of different concentrations and combinations of $\mathrm{GA}_{3}$ and IBA with MS medium on root induction and proliferation in somatic embryo derived shoots. Each treatment consisted of 15 explants and data were recorded after 4 weeks of culture.

\begin{tabular}{|c|c|c|c|c|c|c|}
\hline \multirow[b]{2}{*}{$\begin{array}{l}\text { Hormonal } \\
\text { supplements } \\
\left(\mathrm{mgl}^{-1}\right)\end{array}$} & \multicolumn{3}{|c|}{ Cotyledon } & \multicolumn{3}{|l|}{ Midrib } \\
\hline & $\begin{array}{l}\text { Days to } \\
\text { root } \\
\text { initiation }\end{array}$ & $\begin{array}{l}\text { No. } \\
\text { roots/shoot } \\
(\bar{X})\end{array}$ & $\begin{array}{l}\text { Average } \\
\text { Length of } \\
\text { roots }(\mathrm{cm})\end{array}$ & $\begin{array}{l}\text { Days to root } \\
\text { initiation }\end{array}$ & $\begin{array}{l}\text { No. } \\
\text { roots/shoot } \\
(\bar{X})\end{array}$ & $\begin{array}{l}\text { Average } \\
\text { Length of } \\
\text { roots } \\
(\mathrm{cm})\end{array}$ \\
\hline $\mathrm{MS}_{0}$ & $8-11$ & 14 & 10.40 & 8-11 & 13 & 10.85 \\
\hline $1 / 2 \mathrm{MS}_{0}$ & $6-8$ & 14 & 11.25 & $7-9$ & 14 & 11.10 \\
\hline $\begin{array}{l}\mathrm{MS}+\mathrm{IBA}(2.0)+ \\
\mathrm{GA}_{3}(0.5)\end{array}$ & $7-11$ & 11 & 8.45 & $7-11$ & 10 & 8.75 \\
\hline$M S+G A_{3}(0.50)$ & $10-13$ & 10 & 5.50 & $10-13$ & 10 & 4.90 \\
\hline MS+IBA $(0.50)$ & $8-11$ & 13 & 9.75 & 8-11 & 12 & 9.25 \\
\hline $\mathrm{MS}+\mathrm{IBA}(3.00)$ & $6-8$ & 15 & 12.25 & $6-8$ & 14 & 11.95 \\
\hline
\end{tabular}

Among the tested of hormone free MS, $1 / 2$ strength $\mathrm{MS}_{0}, \mathrm{MS}+2.0 \mathrm{mgl}^{-1}\left|\mathrm{BA}+0.5 \mathrm{mgl}^{-1} \mathrm{GA}_{3}, \mathrm{MS}+0.5 \mathrm{mgl}^{-1}\right| \mathrm{BA}$ and $\mathrm{MS}+0.5 \mathrm{mgl}^{-1} \mathrm{GA}_{3}$, the best result for root induction was obtained in MS+3.0 mgl-1/BA (Fig 2C). Average number and mean length of roots were better in MS+3.00 $\mathrm{mgl}^{-1}$ IBA than those of other treatments. Use of $1 / 2$ strength MS was also found to give satisfactory results. Similar results were also reported by others (Uddin et al. 2004). In vitro rooted plantlets were acclimatized carefully and planted in polar pots (Fig 2D) containing sterile sand, soil and compost (1:2:1). In this way, the regenerated plants showed $95 \%$ survival under natural condition.

Information from this study could be used as an alternative path to induce genetic and epigenetic changes in regenerated plants, which eventually can be used for crop improvement program in eggplant. Moreover, callus induction and its subsequent plant regeneration protocol hold great promise for production of transgenic eggplants of desirable traits by genetic transformation techniques.

\section{References}

Alam M F, Swaraz A M, Parvez S, Khan M R and Ahsan N (2002) Development of efficient plant regeneration from leaf discs and internode derived callus in tomato (Lycopersicom esculentum Mill.). Bangladesh. j. genet. biotechnol. 3 (1\& 2): 53-56.

Anisuzzaman M and Joarder O I (1992) Genotypic differences in in vitro response of Solanum melongena L. M Sc Thesis, Department of Botany, University of Rajshahi, pp 107.

Bajaj Y P S (1990) Biotechnology in Agriculture and Forest In: Somaclonal variation in crop improvement. Springer-Verlag (ed.) Berlin 11: 1-685. 
Bose T K, Som G M and Kabir J (1999) Vegetable Crops (4th edtion), Naya Prokash, Calcutta-6. pp 281-333.

Choudhury (1976) Vegetables (4th ed.), National Book Trust, New Dehli, pp.50-58.

Danielle J D and William E V (1988) Glossary of Plant Tissue culture. Belhaven press.pp79.

Evans D A and Sharp W R (1986) Hand Book of Plant Cell Culture Techniques and Applications. In: Somaclonal and gametoclonal variation. MacMillan Publishing Company, NY 4: 97-132.

Haider S A and Joarder O I (1992) Studies on in vitro propagation of Abelmoscus esculentus (L.) Moench. M Sc Thesis, Department of Botany, University of Rajshahi.

Hena M A (1991) Studies on the in vitro regeneration of eggplant (Solanum melongena $L$ ) through somatic embryogenesis. M Sc Thesis. Department of Botany, University of Rajshahi. pp-25.

Ishak Z, Imanishi S, Egashira H and Suzuki H (1992) Effect of sterilization and medium composition on germination of tomato seeds (Lycopersicom esculentum Mill) .J. Yamagata Agr. For. Soc. 49: 7-11.

Kumar K D (1995) An Introduction to Plant Tissue Culture. New Central Book agency, Calcutta pp 80.

Larkin P J and Scowcroft W R (1986) Somaclonal variation a novel source of variability from cell cultures for plant improvement. Theor. App. Genet. 60:197-214.

Murashige T and Skoog F (1962) A revised medium for rapid growth and bioassays with tobacco tissue cultures. Physiol. Plant. 15: 443-497.

Niedz R P, Rutter S M, Handley L W and Sink K C (1985) Plant regeneration from leaf protoplast of six tomato cultivars. Plant sci. 39: 199-201.

Singh S, Krisnamurthi S and Katial S L (1984) Fruit culture in India. Indian Council of Agricultural Research, New Dehli. pp 412.

Uddin M N, Bari M A and Rahman M (2004) Meristem Culture in Eggplant (Solanum melongena L.) for Production of Disease free Cultivars in Bangladesh. J.bio-sci. 12: 117-123.

Zahurul A M (1969) Insect pest of vegetables and their control in East Pakistan. Publisher pp 3-30.

Zelcer A, Siferman $O$ and lzhar S (1984) An in vitro screening for tomato genotypes exhibiting efficient shoot regeneration. J. Plant Physiology.115 (3): 211-215. 